\title{
Nexus of Climate Change and USA Mid-South Rice (Oryza sativa L.) Production
}

\author{
Michael Aide ${ }^{1}$, Christian Torres De Guzman ${ }^{2}$ \\ ${ }^{1}$ Department of Agriculture, Southeast Missouri State University, Cape Girardeau, MO, USA \\ ${ }^{2}$ University of Arkansas, Fayetteville, AR, USA \\ Email: ^mtaide@semo.edu
}

How to cite this paper: Aide, M., \& De Guzman, C. T. (2020). Nexus of Climate Change and USA Mid-South Rice (Oryza sativa L.) Production. Journal of Geoscience and Environment Protection, 8, 211231.

https://doi.org/10.4236/gep.2020.812013

Received: November 23, 2020

Accepted: December 22, 2020

Published: December 25, 2020

Copyright $\odot 2020$ by author(s) and Scientific Research Publishing Inc. This work is licensed under the Creative Commons Attribution International License (CC BY 4.0).

http://creativecommons.org/licenses/by/4.0/

\begin{abstract}
Climate change is manifesting across the USA Mid-South and is impacting agricultural productivity, including the production of rice. This manuscript is a review of pertinent global literature concerning the effect of increasing temperature and carbon dioxide concentrations involving: 1) rice growth and development with an emphasis on spikelet sterility, 2) water availability for irrigation with the specter of aquifer overdraft and emerging water management technologies intended to improve water use efficiency, 3) the soil-plant continuum related to greenhouse gas emission and research avenues supporting agronomic practices that limit these emissions, and 4) region wide assessment of the economic and agronomic indicators to infer changes in the agricultural infrastructure and markets. Based on the global literature review and specific circumstances for USA Mid-South rice production, explicit proposals to mitigate and alleviate climate change are proposed. Key climate change mitigation proposals include: 1) support irrigation technologies that limit water usage and reduce methane emissions, 2) support soil carbon enhancement and newly emerging soil health agronomic practices, 3) achieve a greater usage of remote sensing activities to detect, in real time, field stresses, 4) support rice breeding activities that benefit furrow irrigation and provide heat tolerance, and 5) coordinate a rice region wide consensus to achieve farm gate activities that address climate change.
\end{abstract}

\section{Keywords}

Climate Change, Rice, Methane Emissions, Furrow Irrigation, Spikelet Sterility

\section{Introduction}

Climate change is real, and its tangible effects are measurable. In the USA Mid- 
South and in other rice (Oryza sativa L.) producing regions, producers are experiencing increasing instances of spikelet sterility because of high nighttime temperatures, delayed planting because of changing rainfall patterns, groundwater and surface water scarcity, and altered plant physiology, nutrient uptake and net photosynthesis. Agriculture, and in particular rice production, is contributing methane and nitrous oxide emissions, accelerating the atmospheric concentrations of these potent greenhouse gases. Recent research is proposing and evaluating technological solutions and assessing emerging agronomic practices to address the deleterious effects of climate change on rice production and reduce the emission of greenhouse gases (Wang et al., 2017).

The research objectives for this manuscript are 1) review the recent global literature addressing climate change influencing rice production, with a specific focus on the USA Mid-South rice producing region, 2) assess and credential the climate change rice issues expected to impact Mid-South rice production, and 3) provide explicit pathways for mitigating climate change impacts on rice production.

\section{Study Area}

\section{1) Economics of Rice Production in the Mid-South USA}

The Mid-South USA rice (Oryza sativa "indica") producing region encompasses the states of Texas, Louisiana, Mississippi, Arkansas, and Missouri. Most of the rice production in Mississippi, Arkansas and Missouri is in the lower Mississippi River embayment; thus, it represents a fluvial landscape. Most rice in Texas and Louisiana is located on coastal plain or smaller river floodplains. The east-central Arkansas Grand Prairie Region is also a major rice producing region. From a global perspective, rice production in the USA is not a dominant crop; however, USA rice production does contribute to the global export capacity. In the USA, rice production centers around 1.1 million ha with an average recent annual yield near $8.3 \mathrm{Mg} \cdot \mathrm{ha}^{-1}$. Prior to milling, annual USA Mid-South rice production is approximately 7251 million $\mathrm{kg}$ (Table 1 ).

\section{2) Typical Rice Growing Practices in the Mid-South USA}

Rice production across the Mid-South USA is typically characterized as having moderate to high temperatures (Missouri July minimum temperatures typically range from an average $19^{\circ} \mathrm{C}$ to $24^{\circ} \mathrm{C}$ and Missouri July maximum temperatures range from $27^{\circ} \mathrm{C}$ to $34^{\circ} \mathrm{C}$ ), abundant radiant energy (July total daily solar radiation values range from 17 to $28 \mathrm{MJ} \cdot \mathrm{m}^{-2}$ for clear skies), level-land that is land-graded, plentiful groundwater and other water resources for irrigation, and soils that inhibit deep water percolation. Oryza sativa "indica" varieties are typically planted. Approximately $2 / 3$ of the annual water requirements for rice are from groundwater and freshwater reserves, with the remaining water requirements supplied by rainfall.

Mid-South rice production is characterized as drill-seeded and delayed flood with ponding initiated at the $4^{\text {th }}$ or $5^{\text {th }}$ leaf stage. Soils are well-prepared to provide a firm and weed-free seedbed, with most of the rice planted in 15 to $25 \mathrm{~cm}$ 
Table 1. Mid-south rice production data for 2019 by rice producing state.

\begin{tabular}{|c|c|c|c|}
\hline State & Category & Production $\left(\mathrm{kg}{ }^{\star}\right.$ million $)$ & Value $\left(\${ }^{*}\right.$ million $)$ \\
\hline & Total & 4280 & \\
\hline \multirow[t]{3}{*}{ Arkansas } & Long & 3586 & 985.8 \\
\hline & Medium & 691 & \\
\hline & Total & 1341 & \\
\hline \multirow[t]{3}{*}{ Louisiana } & Long & 1170 & 309 \\
\hline & Medium & 186 & \\
\hline & Total & 422 & \\
\hline \multirow[t]{3}{*}{ Mississippi } & Long & 414 & 95.4 \\
\hline & Medium & 7 & \\
\hline & Total & 648 & \\
\hline \multirow[t]{3}{*}{ Missouri } & Long & 621 & 153 \\
\hline & Medium & 27 & \\
\hline & Total & 560 & \\
\hline \multirow[t]{2}{*}{ Texas } & Long & 552 & 140 \\
\hline & Medium & 8 & \\
\hline USA & Total & 7251 & 1683.00 \\
\hline
\end{tabular}

Source: https://www.nass.usda.gov (USDA National Agricultural Statistics Service).

rows at the planting depth of $1 \mathrm{~cm}$ or less. A minority of rice planting is broadcasted. On clayey soils, some producers utilize a stale seedbed with no-till to reduce the accumulation of coarse aggregates. During dry periods, fields are "flushed", which is spreading a temporary water layer to promote rice seed germination and water-activation of selective herbicides (Moldenhauer et al., 2013).

Two common nitrogen fertilization programs include: 1) a two-way split with approximately $65 \%$ to $75 \%$ of the total nitrogen applied immediately prior to flood application with the remainder applied at beginning internode elongation, or 2) all nitrogen applied preflood. Urea (46-0-0) or ammonium sulfate (21-0-0) $24 \% \mathrm{~S}$ are commonly used nitrogen fertilizer materials. Common rotations involve rice-soybean (Glycine max (L.) Merr.) and continuous rice. In Louisiana and Texas, producers may employ a ratoon rice crop post-harvest of the early season rice crop. Rice harvest involves field draining and a period of soil drying before combine harvest (Smartt et al., 2016). Many producers store grain on premise until markets indicate transfer to commercial buyers.

Recently, rice producers have expanded the usage of furrow irrigation on gradedland (Nalley et al., 2015). In furrow irrigated rice, groundwater is pumped and then transferred in flexible plastic tubing and applied at the upper end of the field (side inlet water application). Producer advantages of furrow irrigation include: a) water conservation, b) reduced levee construction, c) lower production costs, and d) smaller arsenic concentration in rice. Current producer disadvan- 
tages of furrow irrigation include: a) greater emphasis on weed management, b) nitrogen losses attributed to nitrification-denitrification, c) lack of crop insurance, d) less predictable yield potential, e) need for disease resistance in plant materials, and f) producer education (Aide \& Goldschmidt, 2017).

\section{Influence of Climate Change on Rice Development and Water Resources}

1) Defining Greenhouse Gases, Global Warming Potential and Carbon Dioxide Equivalent

Greenhouse gases (GHGs) are defined as gases in the earth's atmosphere that absorb energy and slow the rate at which energy escapes the planet. Water vapor is a greenhouse gas; however, with daily variations in humidity, water vapor is treated separately from other greenhouse gases.

Global Warming Potential (GWP) is an estimate of the amount of energy absorbed from a unit mass of a specific gas that was emitted compared to the same emission mass of carbon dioxide. Generally, the amount of energy absorbed is estimated for a 100-year time frame. Typical GWP values for methane $\left(\mathrm{CH}_{4}\right)$ range from 25 to 36, with an atmosphere residence of 10 years (Smartt et al., 2016; Simmonds et al., 2015; Horie, 2019). Nitrous oxide $\left(\mathrm{N}_{2} \mathrm{O}\right)$ has GWP values ranging from 265 to 298, with an atmosphere residence time of more than 100 years. Other GHGs include chlorofluorocarbons (CFCs), hydrofluorocarbons (HFCs), ozone $\left(\mathrm{O}_{3}\right)$, perfluorocarbons (PFCs), nitrogen trifluoride $\left(\mathrm{NF}_{3}\right)$, and sulfur hexafluoride $\left(\mathrm{SF}_{6}\right)$. Chlorofluorocarbons, hydrofluorocarbons, perfluorocarbons, and sulfur hexafluoride $\left(\mathrm{SF}_{6}\right)$ are estimated to have exceptionally long atmospheric residence durations. Carbon dioxide equivalent $\left(\mathrm{CO}_{2} \mathrm{e}\right.$ or $\left.\mathrm{CDE}\right)$ is determined by the product of the gas concentration and its GWP.

Carbon dioxide accounts for approximately $75 \%$ of the global GHG emission, with fossil fuel, deforestation, and biomass decomposition the leading sources. Carbon dioxide concentrations during the Industrial Revolution were approximately 280 ppm, currently $\mathrm{CO}_{2}$ concentrations center near 395 ppm (Conrad, 2009). Methane and nitrous oxide account for the majority of the remaining GHG emissions, with important sources including: a) enteric fermentation, b) fertilizer management, c) rice production, d) manure management, e) waste management, and f) energy utilization. Nitrous oxide concentrations in 1750 were estimated to be near $180-260 \mathrm{ppb}$, whereas current estimates have $\mathrm{N}_{2} \mathrm{O}$ position near 320 ppb (Conrad, 2009).

2) Influence of High Temperature and other Meteorological Variables on Rice Growth and Development

The specter of increasing temperature associated with climate change may be deleterious to rice production (Krishnan et al., 2011). Currently, most rice breeders view high temperature-induced spikelet sterility with alarm. Many studies have focused on high nighttime temperatures as more critical than high daytime temperatures. Wichelns (2016), in a review, noted that climate change 
will likely manifest as increased minimum and maximum daily temperatures and changes in the timing, intensity, and duration of rainfall. Wichelns also reported on studies indicating that increased $\mathrm{CO}_{2}$ and increased temperatures may synergistically further spikelet sterility. High temperature impacts on pollen viability and spikelet sterility are more prominent in indica cultivars than japonica cultivars, a feature partially attributed to enhanced nighttime temperatures having a smaller influence on carbon assimilation for indica cultivars (Horie, 2019).

Ali et al. (2013) observed rice variety variations from the Australian rice breeding program for yield response during the reproductive and grain fill stages. Noting that rice plants are particularly sensitive to high temperature stress during gametogenesis (microspore and megaspore formation) and that spikelet sterility may limit yield, they observed high temperature stress from panicle exertion to late grain fill. Rice yield losses attributed to applied heat stress were greatest from panicle exertion to anthesis; however, significant genotype and heat stress interaction differences were documented. No variety showed the same degree of heat tolerance across all of the stress tested growth stages. In Indonesia, Hidayati et al. (2016) compared photosynthesis and transpiration rates in systems of rice intensification with traditional systems. Using less water, the system of rice intensification showed a) greater shoot dry weight, b) greater number of productive tillers, c) greater rates of photosynthesis, d) improved chlorophyll $a$ and $b$ contents from flowering to mature grain, e) increased grain weight at harvest, f) greater root mass, and g) greater nutrient uptake. Transpiration rates and leaf temperatures were not significantly different.

In the Mekong Delta of Vietnam, Jiang et al. (2019) performed a climate-crop study and documented that rain-fed, winter rice yields were expected to experience a $24 \%$ reduction and rain-fed summer rice yield were expected to decline $49 \%$ because of expected climate change. Irrigated rice yields were only incidentally expected to decline because of expected climate change. Trisurat et al. (2018) inferred basin-wide impacts were expected because of climate change within the lower Mekong basin, demonstrating regional differences that may shift rice production and food security. In southeastern China, Yang et al. (2017) compared controlled irrigation and flood irrigation (traditional). A decrease of $46 \%$ irrigation water usage did not influence rice yield but did improve water use efficiency. Soil respiration in the controlled irrigation fields was greater, except during the ripening stage. Ye et al. (2019) supported the premise that earlier phenological dates and long-duration varieties offset the impact of climate change. In California, Sharifi et al. (2018) showed that water temperatures (away from the inlet) from planting to booting were $2.6^{\circ} \mathrm{C}$ greater than air temperatures. Water temperatures improved the accuracy of rice phenology models. In Arkansas, Ortega et al. (2019) showed that high night-time temperatures supported bacterial panicle blight (Burkholder glumae).

Liu et al. (2019) completed a soil fertility study involving nitrogen, phosphorus, potassium, and silicon with contrasting high daytime temperatures. High 
day time temperatures decreased grain yield and decreased the transference of nitrogen, phosphorus, and potassium to panicles. Under conditions of high day time temperatures, silicon fertilization improved grain yield and the nitrogen, phosphorus, and potassium translocation to panicles. Wang et al. (2018) in eastern China performed a field experiment involving elevated $\mathrm{CO}_{2}$ concentrations and elevated air temperatures. The enhanced $\mathrm{CO}_{2}$ content supported greater wheat (Triticum aestivum L.) and rice yields; however, protein contents declined. The implication was that climate change may support $\mathrm{CO}_{2}$ enrichment that improves yield; however, grain quality may be negatively affected. In Arkansas, Esquerra et al. (2019) tested rice varieties at the $\mathrm{R}^{2}$ stage (flag leaf collar formation) and R5 (elongation of at least one grain on the panicle) for two elevated nighttime temperatures (control at $23^{\circ} \mathrm{C}$ and a high night-time temperature at $28^{\circ} \mathrm{C}$ ). Spikelet fertility and yield were reduced for some varieties for high nighttime temperatures imposed at $\mathrm{R}^{2}$ (flag leaf collar). The specter that rice breeding for high nighttime temperature tolerance is promising.

In a comprehensive review Horie (2019) employed simulation modeling to discern rice production regions across Asia that are susceptible to climate change and rice production. The dynamic process model named SIMRIW and its succeeding model GEMRICE assumed a doubling of the pre-industrial atmosphere $\mathrm{CO}_{2}$ content and projected global warming temperatures for irrigated rice. Regions identified as most susceptible to global warming and increased spikelet sterility include Thailand-Myanmar, east-central China, northern and southeastern India. Input data for these models required detailed information concerning elevated temperature effects on rice growth and development, especially influences on spikelet sterility. A considerable amount of research was cited, much of it provided by the author employing temperature gradient chambers, to calibrate the simulation models. Based on a compelling review, the author noted that given a doubling of $\mathrm{CO}_{2}$ atmosphere content then fundamental trends or data requirements were likely. Key fundamental trends include: a) under optimum nitrogen availability rice biomass increased $24 \%$ between 24 to $31^{\circ} \mathrm{C}$, b) panicle weight decreased as the average temperatures exceeded $29^{\circ} \mathrm{C}$ regardless of $\mathrm{CO}_{2}$ content, c) panicle weight reductions at higher temperatures were attributed to spikelet sterility, d) leaf area index was consistent regardless of temperature, thus the increased biomass was attributed to enhance photosynthesis, e) water use efficiency was improved because of the increase of biomass and photosynthesis, $f$ ) panicle yield increased because of improved tillering, g) indica genotypes showed higher responses to enhanced atmosphere $\mathrm{CO}_{2}$ than Japonica genotypes, and h) spikelet sterility was attributed to pollination failure. Horie (2019) also discussed literature demonstrating that reduced incidence of spikelet sterility in hot and dry regions may be attributed to transpiration cooling of the canopy.

Arnell et al. (2019) investigated global and regional impacts involving 30 indicators (examples included major heat wave frequency, hydrological drought time, reduction in crop growth duration, river flooding, etc.) because of in- 
creased temperature. Concerning rice, the authors inferred that the likelihood of hot spell frequency and rainfall reduction increase in proportion to the magnitude of the temperature increase. Xie et al. (2019) estimated crop yields and planted area on a county level for selected states along the Mississippi River and inferred the production response to climate change. Model predictors included spatially explicit soil data, a fine scale weather data set, and satellite crop coverage. Rice yields in the USA Mid-South were predicted to slightly decrease; however, planted acre estimates were expected to increase because of land expansion to rice at the expense of corn (Zea mays L.). In China, Chen \& Tian (2016) used province level yield data and historical weather data to determine that elevated minimum daily temperatures increased early and late rice yields. The magnitude of the rice yield improvement because of elevated minimum nighttime temperatures varied by variety and growth stage.

\section{3) Sustainability of Ground Water Resources}

In Missouri, as in other rice producing states, groundwater resources substantially augment rainfall for rice and other row crops (Massey et al., 2014). The Mississippi River Valley Alluvial Aquifer (MRVAA) in Arkansas, Mississippi, and Missouri is the major ground water resource for rice irrigation. In general, the MRVAA is an unconfined aquifer in Missouri, whereas the MRVAA varies from an unconfined to confined aquifer in Arkansas. Aquifer recharge is by rainfall and base flow from the Mississippi River, other rivers and streams, drainage ditches and surface water bodies. In the state of Mississippi, Massey et al. (2017) documented that rice receives greater quantities of water $\left(9200 \mathrm{~m}^{3} / \mathrm{ha}\right)$ than maize $\left(3100 \mathrm{~m}^{3} / \mathrm{ha}\right)$, soybeans $\left(2800 \mathrm{~m}^{3} / \mathrm{ha}\right)$ and cotton $\left(1800 \mathrm{~m}^{3} / \mathrm{ha}\right)$. In Louisiana, excessive groundwater withdrawal from the Coastal Lowland Aquifer system is also a concern.

There is growing concern that ground water withdrawal rates exceed recharge rates, leading to declining water tables or equipotential surfaces (Reba et al., 2017). The United States Geological Survey (USGS) has established a series of observation wells across the USA

[https://www.usgs.gov/mission-areas/water-resources/data-tools] (verified 14 November 2020). Selecting one observation well from Missouri (Figure 1) and one observation well from Arkansas (Figure 2) illustrate regional differences in aquifer overdraft potential. The Missouri observation well, located in Qulin, Missouri, shows no overdraft history, whereas the water table drawdown only exists during the irrigation season. Rainfall and base flow return refurbishes the aquifer to its normal level by the beginning of the next irrigation season. Conversely, the observation well located in Lonoke, Arkansas, shows a continuous reduction of the water table elevation with little evidence that annual recharge is sufficient (Figure 2). Currently significant cones of depression exist in the Grand Prairie region and west of Crowley's Ridge, both in Arkansas (Reba et al., 2017).

To address water aquifer overdraft concerns, the United States Department of Agriculture and selected institutions of higher education have teamed with 


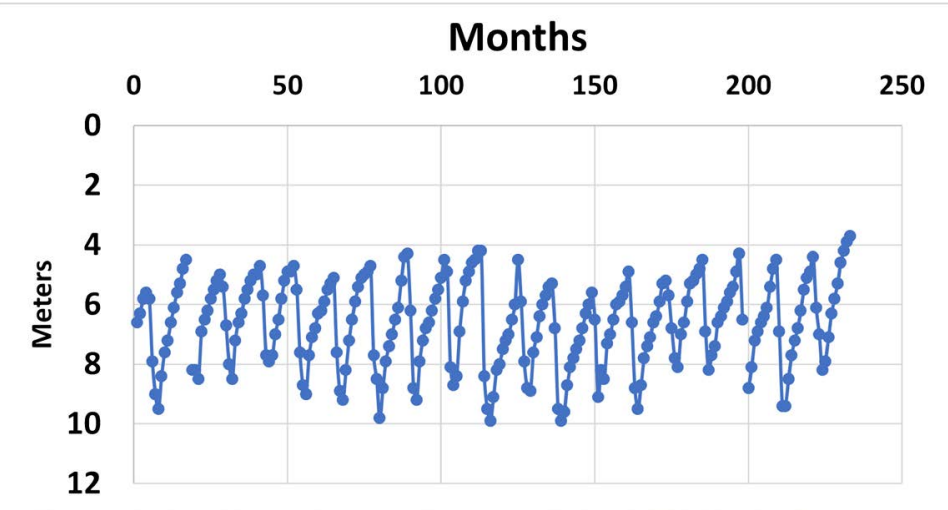

Figure 1. Depth to water table for united states geological survey well in Qulin, Missouri.

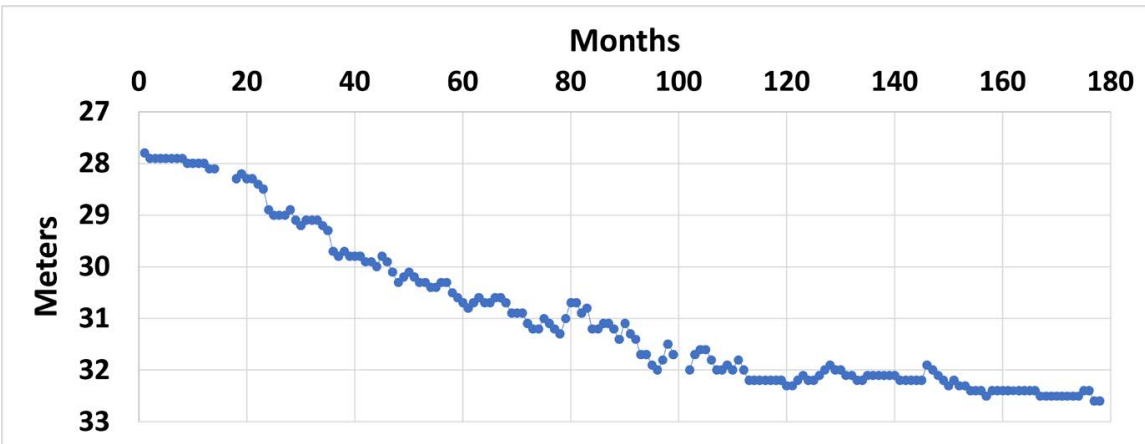

Figure 2. Depth to water table for united states geological survey well in Lonoke, Arkansas.

commodity groups to apply technological solutions. Key technological solutions center on irrigation efficiency. Cascade flood irrigation of rice involves application of water to an elevated rice field, allowing water flow through rice gates across a series of decreasing elevation rice fields. The introduction of multiple-inlet irrigation reduced water consumption by approximately $20 \%$, with a key feature reduced overwatering the lowermost fields. Multiple-inlet irrigation employs flexible plastic tubing laid along a land-graded field edge, where water is applied to the upper end of the field via prescribed holes in the tubing. Water transverses the field and is either collected by a field ditch or retained in the field by a levee. Tailwater recovery is an attempt to collect excess irrigation water and reapply the water. Other innovations include the usage of surge pumps to alternate water applications along the side-inlet location to permit a more uniform depth of soil water infiltration. Recently alternate wetting-drying and furrow irrigation has the potential to reduce field runoff, employ smaller amounts of water and maintain high rice yields (Aide, 2019b).

\section{Interactions between Climate Change and the Soil Resource}

1) The Soil Processes of Nitrous Oxide $\left(\mathrm{N}_{2} \mathrm{O}\right)$ Synthesis and Emission in Rice Systems

Consider a rice paddy with $15 \mathrm{~cm}$ (6 inches) ponded water. The atmospheric 
partial pressure of oxygen $\left(\mathrm{P}_{\mathrm{O}_{2}}=0.21 \mathrm{~atm}\right)$ permits partial oxygenation of the water layer with some oxygen diffusion extending into the uppermost soil layer. Abiotic and biotic factors in the paddy water, some of which are temperature dependent, will consume a portion of the paddy water oxygen (Vepraskas et al., 2001). The uppermost layer of soil will likely alternate from suboxic to anoxic, whereas deeper soil increments will be progressively and continuously become more anoxic. The presence of the rice plant will also encourage suboxic to oxic root rhizosphere intervals because of $\mathrm{O}_{2}$ transport via the aerenchyma vascular system. In furrow irrigated rice and alternate wetting and drying rice systems, the greater likelihood of suboxic and oxic conditions, presumably also having longer durations, encourage the nitrification and denitrification sequence. The microbial-mediated denitrification process is represented by the half-cell reaction:

$$
2 \mathrm{NO}_{3}^{-}+12 \mathrm{H}^{+}+10 \mathrm{e}^{-}=\mathrm{N}_{2}+6 \mathrm{H}_{2} \mathrm{O} .
$$

In the Mid-South USA, rice fertilization is almost exclusively urea (46-0-0) or ammonium sulfate (21-0-0)24S. Conversion of urea to ammonium $\left(\mathrm{NH}_{4}^{+}\right)$is frequently constrained using urea-impregnated urease inhibitors to support a more controlled ammonium delivery. During intervals where ammonium exists in a suboxic to oxic soil environment, nitrification will allow the sequential conversion of ammonium to nitrite $\left(\mathrm{NO}_{2}^{-}\right)$and then to nitrate $\left(\mathrm{NO}_{3}^{-}\right)$. Optimum soil nitrification temperatures center around $30^{\circ} \mathrm{C}$. With a return to increasing anoxic soil conditions, denitrification supports nitrate reduction to either $\mathrm{N}_{2}$, $\mathrm{NO}$ or $\mathrm{N}_{2} \mathrm{O}$. At pH levels greater than six, $\mathrm{N}_{2}$ is the dominant bi-product of denitrification; however, at $\mathrm{pH}$ levels more acid than $\mathrm{pH} 5.5$, nitric oxide (NO) is the dominant denitrification product. Between $\mathrm{pH} 5.5$ and $\mathrm{pH}$ 6, the dominant denitrification bi-product is the GHG nitrous oxide $\left(\mathrm{N}_{2} \mathrm{O}\right)$. Typically, the shift from oxic to anoxic soil oxidation-reduction status supports a $\mathrm{pH}$ shift towards a neutral reaction. Soils having an acidic reaction may be more likely to have a $\mathrm{pH}$ interval supporting nitrous oxide emission.

2) The Soil Processes of Methane $\left(\mathrm{CH}_{4}\right)$ Synthesis and Emission in Rice Systems

Understanding the soil chemistry of methane emissions arising from rice production is a global research activity, with considerable emphasis focusing on the role of soil texture (Rogers et al., 2013), rice residues (Rogers et al., 2014; Suduan et al., 2004; Fitzgerald et al., 2000; Sass, 1991a; Sass, 1991b), water management (Aide, 2019b; Atwill et al., 2018; Carrijo et al., 2018; Wu et al., 2017; Kreye et al., 2007; Fitzgerald et al., 2000; Cai et al., 1997) and cultivar selection (Lunga et al., 2019; Zheng et al., 2018; Sharma et al., 2016; Simmonds et al., 2015). The rice plant's root, culm, and leaf structures possess aerenchyma tissue; that is, spongy tissues that possess connected spaces within and across the leaves, stems, and roots, facilitate gas exchange between the soil and atmosphere. These spongy tissues provide a direct conduit from the root rhizosphere to the atmosphere that permit methane emission rates that precisely exceed soil diffusion 
rates (Groot et al., 2005; Das \& Baruah, 2008; Aulakh et al., 2000; Byrd et al., 2000; Butterbach-Bahl et al., 1997).

Methane generation requires an absence of oxygen and other electron acceptors, such as nitrates, Fe-oxyhydroxides, and sulfates. Flooded soils alter key soil properties, such as gaseous diffusive and convective flux (Smartt et al., 2016; Brye et al., 2013; Huang et al., 2002). In fine-textured soils, as the moisture content increases, pore space connectivity and tortuosity reduce gaseous flux. With the advent of reduced soil conditions and the presence of particulate soil organic matter, humus decomposition slows. Well-aerated soils may have an Eh near $700 \mathrm{mV}$; however, oxygen reduction occurs largely in the 380 to $320 \mathrm{mV}$ range. Nitrate reduction to $\mathrm{N}_{2}, \mathrm{NO}$ and $\mathrm{N}_{2} \mathrm{O}$ occurs in the Eh range of 280 to $220 \mathrm{mV}$ range. Similarly, $\mathrm{MnO}_{2}$ and $\mathrm{Fe}_{2} \mathrm{O}_{3}$ reduction to $\mathrm{Mn}^{2+}$ and $\mathrm{Fe}^{2+}$ occurs in the 220 to $180 \mathrm{mV}$ and 110 to $80 \mathrm{mV}$ range, respectively. Sulfate $\left(\mathrm{SO}_{4}^{2-}\right)$ reduction to sulfide $\left(\mathrm{S}^{2-}\right)$ occurs at -140 to $-170 \mathrm{mV}$, whereas $\mathrm{CO}_{2}$ reduction to methane occurs at -200 to $-280 \mathrm{mV}$ (Smartt et al., 2016). In theory, soil production proceeds in a continuous sequence involving $\mathrm{O}_{2}$ depletion, followed by nitrate reduction, then culminating on methane production; however, soils are heterogenic systems with different oxidation-reduction environments co-existing because of soil texture and soil structure variations.

Pre-industrial levels of methane were estimated to be 715 ppbv, whereas current levels center near 1779 ppbv. Methane sources include: a) mining, fossil fuel, and biomass burning (25\%), b) microbial processes in soil and water (69\%), and c) chemical processes $(6 \%)$ (Conrad, 2002, 2009). Soil may also act as a sink for atmospheric methane because of high affinity methanotrophs (Jia et al., 2001; Hou et al., 2000).

In rice agroecosystems, acetoclastic methanogenesis is one process resulting in the production of methane, a process associated with soil organic matter decomposition to produce acetate, $\mathrm{H}_{2}$ and $\mathrm{CO}_{2}$ (Hou et al., 2000; Lu \& Conrad., 2005). Methanogenic Archaea has been identified at the primary microbial organisms for methane genesis. Within rice soils, methanogens classified as belonging to Rice Cluster 1 have been observed to exist in aerobic soils or oxygenated rhizospheres because of enzyme systems that detoxify $\mathrm{O}_{2}$ species. Rice Cluster 1 species are mesophiles $\left(30^{\circ} \mathrm{C}\right.$ to $\left.40^{\circ} \mathrm{C}\right)$ and neutrophiles ( $\mathrm{pH} 6$ to 8$)$. Hydrogenotropic methanogenesis involves the microbial mediated reaction of $\mathrm{H}_{2}$ and $\mathrm{CO}_{2}$ to yield methane.

Root exudates, livestock manure, green manure, and rice straw have been shown to increase methane production (Aulakh et al., 2001a; Aulakh et al., 2001b; Lu et al., 2000; Lu et al., 1999), however, compost yields a smaller methane production response, presumably because the compost's active carbon composition has already been substantially utilized. In rice, early-season methane production largely results from residue decomposition, whereas late-season methane production results more from rice root senescence attributed to carbohydrate transference away from root development and towards seed development. Nitrogen 
fertilization studies have provided inconsistent results, with many studies documenting a nitrogen-methane linkage response and other studies documenting little nitrogen-methane linkage (Atwill et al., 2018; Bharali et al., 2017; Banger et al., 2012; Cai et al., 1997). In Louisiana, ratoon cropping substantially increased methane emission, a feature attributed to the main rice crop's residue decomposition (Smartt et al., 2016). Cultivar selection has been shown to influence methane emission by having differences in root exudation, dry matter production, plant-mediated diffusion, and altered microbial community dynamics (Das \& Baruah, 2008; Lu \& Conrad, 2005; Kimura et al., 2004; Suduan et al., 2004; Aulakh et al., 2001a; Hou et al., 2000; Lu et al., 2000; Sass et al., 1991a, 1999b). In rice, up to $60 \%$ of the methane emissions arise from microbial utilization of root exudates as a carbon source or from necrotic root decomposition (Conrad, 2009). Enhanced $\mathrm{CO}_{2}$ assimilation supports greater root mass development per unit biomass, thus providing more carbon for methanogenic Archaea (Wichelns, 2016).

Methanotrophs catalyze methane oxidation and have been identified in soil and water environments. Protobacteria utilize methane and methanol as carbon sources. Low-affinity methanotrophs are important in soil environments, operating at the oxic-anoxic interface and in the presence of larger methane concentrations High-affinity methanotrophs are more important in soil environments having low atmospheric methane concentrations, particularly associated with upland soils. High-affinity methanotrophs are not strongly impacted by temperatures changes and tolerate extremely acid to slightly alkaline soil pH levels.

Methane emission from rice fields may occur because of a) diffusion, b) gas bubble migration towards the surface, and c) plant-mediated diffusion. Plantmediated diffusion is the dominant mechanism, responsible for $90 \%$ of the methane emission. Plant-mediated diffusion proceeds because of a methane concentration gradient passageway involving aerenchyma cells; that is, soil to root aerenchyma tissues to shoot/leaf aerenchyma tissues to the atmosphere (Groot et al., 2005; Das \& Baruah, 2008; Aulakh et al., 2000; Byrd et al., 2000; Butterbach-Bahl et al., 1997). Butterbach-Bahl et al. (1997) demonstrated that the lower leaf sheaths provided the most efficient pathway.

3) Influence of Agronomic Practices on Methane and Nitrous Oxide Emissions from Rice Cultivation

Given that global methane and nitrous oxide emissions attributed to rice production are a significant percentage of all GHG emissions, it is not surprising that considerable research has be extended to understand the mechanisms for GHG emission and to provide technology and agronomic practices to mitigate GHG emissions. Zhou et al. (2020) applied rice straw (C/N ratio of 63) and green manure ( $\mathrm{C} / \mathrm{N}$ ratio of 14$)$ separately and in various combinations to assess the benefits on soil health and to determine their influence on GHG emissions. All plant treatments increased $\mathrm{CO}_{2}$ and methane emissions but decreased nitrous oxide emissions. Adding green manure amendments limited nitrogen im- 
mobilization attributed to the rice straw and the addition of rice straw amendments reduced the high carbon and nitrogen losses associated from just amending rice soil with green manure.

Zheng et al. (2018) scrutinized methane emissions from rice cultivars with different levels of radial oxygen loss. Radial oxygen loss was influenced by root numbers, number of root tips per plant and root volume. The authors documented that radial oxygen loss and methane emissions were inversely related. Conrad \& Klose (1999) demonstrated that cleaned and excised rice roots cultured under anaerobic conditions produced hydrogen gas, methane, acetate, propionate, and butyrate. Acetate was produced in the greatest concentration (3.4 \pm $0.6 \mu \mathrm{mol} \cdot \mathrm{h}^{-1} \mathrm{~g}$-dry-weight ${ }^{-1}$ roots). Employing radioactive bicarbonate $/ \mathrm{CO}_{2}$ they reported that carbon was incorporated into methane, acetate, and propionate. After establishing a rice pot culture system, Watanabe et al. (2004) employed labeled ${ }^{13} \mathrm{C}$ at the rice growth stages of a) maximum tillering, b) panicle emergence, and c) beginning seed development. In addition to rice plant uptake, assimilated ${ }^{13} \mathrm{C}$ was detected as methane with the greatest labeled methane concentration detected during early grain development.

In Bangladesh Ali et al. (2013) performed a rice irrigation-soil fertility experiment where urea was amended factorially with a) calcium carbide, b) calcium silicate, c) phosphogypsum, and d) biochar. As a main treatment, irrigation consisted of continuous flood irrigation and intermittent irrigation. As expected, methane emissions were greater for continuous flood and nitrous oxide emissions were greater for intermittent flood. Phosphogypsum and calcium silicate act in soil as electron acceptors and reduced methane emissions $25 \%-27 \%$ under continuous flood and 28\% - 32\% under intermittent irrigation. Biochar and calcium carbide inhibit nitrification and reduced nitrous oxide emission $36 \%$ to $40 \%$ under continuous flood and $26 \%$ to $30 \%$ under intermittent irrigation. In Arkansas, Chlapecka et al. (2019) compared furrow irrigation and alternate wetting and drying rice systems, demonstrating that a) the alternate wetting and drying system favored water conservation and b) rice yields were comparable, supporting a greater water use efficiency. In Missouri, multiple years of furrow-irrigation of rice shows promise in maintaining yields; however, substantial issues remain in securing a consistent a) nitrogen fertilization regime, b) weed management program, and c) irrigation timing protocol (Aide, 2019a; Aide, 2018; Aide \& Goldschmidt, 2017).

In China, Jia et al. (2001) compared methane production, transport, oxidation, and emission in rice producing fields with respect to fallow fields. Methane emissions averaged $261 \mu \mathrm{g} \cdot \mathrm{m}^{-2} \cdot \mathrm{h}^{-1}$ from fields having rice cultivation, whereas fallow fields had methane emission averages of $38 \mu \mathrm{g} \cdot \mathrm{m}^{-2} \cdot \mathrm{h}^{-1}$. Methane emissions were greater during rice tillering than at panicle initiation, a feature attributed to a oxidation of $54 \%$ of the root rhizosphere methane during panicle initiation and oxidation of $36.3 \%$ of the root rhizosphere methane during tillering. Methane production was inferred to have been supported by carbohydrate and amino ac- 
id release to the rhizosphere.

In India, Gorh \& Baruah (2019) conducted a two-year trial involving eight rice varieties to estimate their global warming potential and greenhouse gas intensity. The global warming potential ranged from 841 to $1289 \mathrm{~kg} \mathrm{CO}$-equivalent.ha ${ }^{-1}$ and the greenhouse gas potential ranged from 0.18 to $0.85 \mathrm{~kg} \mathrm{CO}_{2}$ equivalent $\cdot \mathrm{kg}^{-1}$ grain yield, demonstrating considerable varietal differences. Global warming potential correlated with the rates of stomatal conductance and transpiration. Sharma et al. (2016) investigated methane emissions across various rice varieties having different nitrogen management treatments with the main treatments involving a) rice transplanting into flood and an b) aerobic system. As expected, methane emissions were greater for the flood system. When compared to urea, other nitrogen treatments consisting of manure, a biofertilizer and vermicompost supported a greater methane release. In California, Cao et al. (2004) documented that rice straw incorporation supported more intense anoxic soil conditions and enhanced the soil environment for methane generation.

Lunga et al. (2019) in a greenhouse project recorded methane, nitrous oxide and carbon dioxide emissions involving direct seeded rice under three water systems: a) flood, b) saturated, and c) below saturation but exceeding field capacity (slightly aerobic). They documented that the above ground biomass was greatest for the flood system; however, the root mass was not significantly different because of a large variance. The flood irrigation system provided greater methane and carbon dioxide emissions; however, the nitrous oxide emissions were equivalent across the three irrigation systems. In China, Tan et al. (2018) observed alternate wetting and drying rice systems and recorded gross nitrification and denitrification rates at various rice growth stages. Nitrification rates ranged from 1.18 to $30.8 \mathrm{mg} \mathrm{N} \cdot \mathrm{m}^{-3} \cdot \mathrm{h}^{-1}$, whereas denitrification rates ranged from 0.65 to $13.54 \mathrm{mg} \mathrm{N} \cdot \mathrm{m}^{-3} \cdot \mathrm{h}^{-1}$. As expected, nitrification rates diminished with higher soil temperatures and the denitrification rates increased at greater soil water contents.

In the Indo-Gangetic plains, Bhatia et al. (2005) demonstrated that manure, green manure, and crop residues supported soil health, but methane emissions were $60 \%$ greater when compared to urea. In both California and Arkansas, Adviento-Borbe et al. (2014) demonstrated that rice yield-scaled global warming potentials were not influenced by the rate of urea application, implying the urea usage for optimal rice yields did not promote higher GHG emissions. Yuan et al. (2019) investigated rice organic fertilization to determine the mechanism for methane emission. Application of ${ }^{13} \mathrm{CO}_{2}$ at rice tillering resulted in a) $28.6 \%$ the labeled ${ }^{13} \mathrm{C}$ assimilated into the rice plants, b) $0.4 \%$ resided in soil, and c) $6.5 \%$ resided in methane. Increased methane emissions from organic fertilization were attributed to increased soil $\mathrm{C}$ and photosynthesis-derived nitrogen, potassium, phosphate, and acetate. Organic fertilization increased the population of the methanogen Methanosarcina. Bharali et al. (2017) observed that inorganic NPK with Sesbania aculeata as green manure increased the global warming potential 
when compared to NPK fertilization without green manure. Application of NPK with Azolla compost increased the global warming potential when compared to NPK fertilization without Azola compost. In a review, Kimura et al. (2004) reported that rhizodeposition is the main carbon source for methane production. In a review, Conrad (2009) documented that most of the methane emissions from rice fields may be attributed to decomposition of root exudates and necrotic rice roots.

\section{Climate Change Prospects for the Mid-South USA and Technology-Based Mitigation Strategies}

The United States Environmental Protection Agency (2016) forecasts that the USA Mid-South region will witness a) greater likelihood of inland water flooding with increasing rainstorm intensity, especially in fall and winter, b) drought risk will increase in summer, and c) greater frequency of daytime temperatures exceeding $35^{\circ} \mathrm{C}\left(95^{\circ} \mathrm{F}\right)$. These forecasts imply that a) flood-induced delayed spring plantings may be more frequent, b) increased irrigation and greater likelihood of aquifer overdraft, c) greater need for high-temperature tolerant cultivars, d) amplified insect, disease and weed pressures imply the creation of improved integrated pest management approaches, and e) augmented producer-oriented education programs promote emerging technology farmgate acceptance.

To address the increasing climate change influence on rice production important technologies and activities must be further refined and implemented:

1) Improvements in irrigation technology to conserve ground water resources. Continued acceptance and adaption of furrow irrigated rice is integral to limiting aquifer overdraft. Advantages of furrow irrigation include: a) 5 to $8 \mathrm{~cm}$ of water may be rapidly applied to recharge depleted soil moisture, b) the initial capital investment is comparatively low providing the field is land graded, c) water application is not substantially impacted if the irrigation water has colloidal material, and d) irrigation water is not applied to foliage. Implementation of surge technology supports a more uniform water application across the field. Disadvantages include: a) the need to apply water more frequently than for other row crops to avoid yield regression, and b) better integration of water application and the nitrogen management program to avoid nitrification-denitrification induced nitrogen losses. Furrow irrigation will reduce methane emission; however, nitrous oxide emissions will likely increase as the denitrification-nitrification cycle will become synchronous with the water application cycle.

2) Rice breeding programs must continue delivering high nighttime tolerant cultivars. As furrow irrigation continues to expand, rice breeding programs must continue to develop cultivars better suited for this irrigation practice, including yield stability, reduced chalk and better disease packages, especially for blast (Magnaporthe grisea) and bacterial blight (Xanthomonas oryzae pv. Oryzae).

3) Research investment and producer-oriented financial support for enhanc- 
ing soil carbon enhancement/maintenance. Obvious emerging practices include cover crops, conservation tillage, and residue management; however, pragmatic issues include the producer desire for furrow irrigation across all crops necessitates full-tillage practices and cover crops have the burden of high seed costs and chemical burndown.

4) A region wide assessment plan for estimating a) current groundwater abundance and water quality, and b) estimated future aquifer withdrawal rates based on current and acceptance of conservation farming practices. The assessment plan must include a) infrastructure developments for surplus water capture, b) wetland preservation, c) irrigation technology for the efficient application of water, and d) for each of the major crops, the anticipated harvested land area changes because of markets and climate change.

5) Development of unmanned aerial vehicles equipped with remote sensing technology to detect stress in rice and then provide real-time management solutions. Further development of cloud-based information systems receives data from tractor-implements to create innovative field management databases for yield and crop quality realization.

6) Sadly, continue to educate citizens that climate change is a reality.

\section{Summary}

The opinion of the authors is that technology and sustainable farming practices must be supported across the agricultural landscape. The six proposed technologies and activities listed in "Climate Change Prospects for the Mid-South USA and Technology-based Mitigation Strategies" are a spanning set of ideas that will be articulated across the USA Mid-South with the goal that they will be properly accepted and advanced. Each rice producing region similarly should propose their set of climate change mitigation goals that make sense for their region, its unique circumstances, and likelihood for implementation.

\section{Conflicts of Interest}

The authors declare no conflicts of interest regarding the publication of this paper.

\section{References}

Adviento-Borbe, M. A., Pittelkow, C. M., Anders, M., van Kessel, C., Hill, J. E., McClung, A. M., \& Linquist, B. A. (2014). Optimal Fertilizer Nitrogen Rates and Yield-Scaled Global Warming Potential in Drill Seeded Rice. Journal of Environmental Quality, 42, 1623 1634. https://doi.org/10.2134/jeq2013.05.0167

Aide, M. T. (2018). Comparison of Delayed Flood and Furrow Irrigation Regimes in Rice to Reduce Arsenic Accumulation. International Journal of Applied Agricultural Research, 13, 1-8.

Aide, M. T. (2019a). Furrow Irrigated Rice Evaluation: Nutrient and Arsenic Uptake and Partitioning. International Journal of Applied Agricultural Research, 14, 15-21.

Aide, M. T. (2019b). Rice Production with Restricted Water Usage: A Global Perspective. 
Egyptian Journal of Agronomy, 41, 197-206.

https://doi.org/10.21608/agro.2019.15729.1174

Aide, M. T., \& Goldschmidt, N. (2017). Comparison of Delayed Flood and Furrow Irrigation Involving Rice for Nutrient and Arsenic Uptake. International Journal of Applied Agricultural Research, 12, 129-136.

Ali, M. A., Hoque, A., \& Kim, P. J. (2013). Mitigating Global Warming Potentials of Methane and Nitrous Oxide Gases from Rice Paddies under Different Irrigation Regimes. Ambio, 42, 357-368. https://doi.org/10.1007/s13280-012-0349-3

Arnell, N. W., Lowe, J. A., Challinor, A. J., \& Osborn, T. J. (2019). Global and Regional Impacts of Climate Change at Different Levels of Global Temperature Increase. Climate Change, 155, 377-391. https://doi.org/10.1007/s10584-019-02464-Z

Atwill, R. L., Krutz, L. J., Bond, J. A., Reddy, K. R., Gore, J., Walker, T. W., \& Harrell, D. L. (2018). Water Management Strategies and Their Effects on Rice Grain Yield and Nitrogen Use Efficiency. Journal of Soil and Water Conservation, 73, 257-264. https://doi.org/10.2489/jswc.73.3.257

Aulakh, M. S., Wassmann, R., Bueno, C., \& Rennenberg, H. (2001a). Impact of Root Exudates of Different Cultivars and Plant Development Stages of Rice (Oryza satiza L.) on Methane Production in a Paddy Soil. Plant and Soil, 230, 77-86.

https://doi.org/10.1023/A:1004817212321

Aulakh, M. S., Wassmann, R., Bueno, C., Kreuzwieser, J., \& Rennenberg, H. (2001b). Characterization of Root Exudates at Different Growth Stages of Ten Rice (Oryza sativa L.) Cultivars. Plant Biology, 3, 139-148. https://doi.org/10.1055/s-2001-12905

Aulakh, M. S., Wassmann, R., Rennnenberg, H., \& Fink, S. (2000). Pattern and Amount of Aerenchyma Relate to Variable Methane Transport Capacity of Different Rice Cultivars. Plant Biology, 2, 182-194. https://doi.org/10.1055/s-2000-9161

Banger, K., Tian, H., \& Lu, C. (2012). Do Nitrogen Fertilizers Stimulate or Inhibit Methane Emissions from Rice Fields? Global Change Biology, 18, 3259-3267. https://doi.org/10.1111/j.1365-2486.2012.02762.x

Bharali, A., Baruah, K. K., Baruah, S. G., \& Bhattacharyya, P. (2017). Impacts of Integrated Nutrient Management on Methane Emission, Global Warming Potential and Carbon Storage Capacity in Rice Grown in a Northeast India Soil. Environmental Science and Pollution Research, 25, 5889-5901. https://doi.org/10.1007/s11356-017-0879-0

Bhatia, A., Pathak, H., Jain, N., Singh, P. K., \& Singh, A. K. (2005). Global Warming Potential of Manure Amended Soils under Rice-Wheat System in the Indo-Gangetic Plains. Atmospheric Environment, 39, 6976-6984. https://doi.org/10.1016/j.atmosenv.2005.07.052

Brye, K. R., Rogers, C. W., Smartt, A. D., \& Norman, R. J. (2013). Soil Texture Effects on Methane Emissions from Direct-Seeded, Delayed-Flood Rice Production in Arkansas. Soil Science, 178, 519-529. https://doi.org/10.1097/SS.0000000000000020

Butterbach-Bahl, K., Papen, H., \& Rennenberg, H. (1997). Impact of Gas Transport through Rice Cultivars on Methane Emission from Rice Paddy Fields. Plant, Cell \& Environment, 20, 1175-1183. https://doi.org/10.1046/j.1365-3040.1997.d01-142.x

Byrd, G. T., Fisher, F. M., \& Sass, R. L. (2000). Relationships between Methane Production and Emission to Lacunal Methane Concentration in Rice. Global Biogeochemical Cycles, 14, 73-83. https://doi.org/10.1029/1999GB001201

Cai, Z., Xing, G., Yan, X., Xu, H., Tsuruta, H., Yagi, K., \& Minami, K. (1997). Methane and Nitrous Oxide Emissions from Rice Paddy Fields as Affected by Nitrogen Fertilizers 
and Water Management. Plant and Soil, 196, 7-14.

https://doi.org/10.1023/A:1004263405020

Cao, S., Tanji, K. K., \& Scardaci, S. C. (2004). Impact of Rice Straw Incorporation on Soil Redox Status and Sulfide Toxicity. Agronomy Journal, 96, 70-76. https://doi.org/10.2134/agronj2004.0070

Carrijo, D. R., Akbar, N., Reis, A. F. B., Li, C., Gaudin, A. C. M., Parikh, S. J., Green, P. G., \& Linquist, B. A. (2018). Impacts of Variable Soil Drying in Alternate Wetting and Drying Rice Systems on Yields, Grain Arsenic Concentration and Soil Moisture Dynamics. Field Crops Research, 222, 101-110. https://doi.org/10.1016/j.fcr.2018.02.026

Chen, X., \& Tian, G. (2016). Impacts of Weather Variations on Rice Yields in China Based on Province-Level Data. Regional Environmental Change, 16, 2155-2162.

https://doi.org/10.1007/s10113-016-0952-0

Chlapecka, J. L., Hardke, J. T., Roberts, T. L., Frizzell, D. L., Castaneda-Gonzalez, E., Clayton, T., Hale, K., Frizzell, T., Duren, M., Mann, M., Clark, S., \& Ablao, A. (2019). Allowable Water Deficit When Utilizing Alternative Rice Irrigation Strategies. In BR Wells Arkansas Rice Research Studies 2019 (170-174). Arkansas Agricultural Experiment Station, Research Series 667. Fayetteville, AR: University of Arkansas System, Division of Agriculture.

Conrad, R. (2002). Control of Microbial Methane Production in Wetland Rice Fields. Nutrient Cycling in Agroecosystems, 64, 59-69.

https://doi.org/10.1023/A:1021178713988

Conrad, R. (2009). The Global Methane Cycle: Recent Advances in Understanding the Microbial Processes Involved. Environmental Microbiology Reports, 1, 285-292. https://doi.org/10.1111/j.1758-2229.2009.00038.x

Conrad, R., \& Klose, M. (1999). Anaerobic Conversion of Carbon Dioxide to Methane, Acetate and Propionate on Washed Rice Roots. FEMS Microbiology Ecology, 30, 147-155. https://doi.org/10.1111/j.1574-6941.1999.tb00643.x

Das, K., \& Baruah, K. K. (2008). Methane Emission Associated with Anatomical and Morphological Characteristics of Rice (Oryza sativa) Plant. Physiologia Plantarum, 134, 303312. https://doi.org/10.1111/j.1399-3054.2008.01137.x

Esquerra, M. Q., Hemphill, C. C., \& Counce, P. A. (2019). Differential Response of Arkansas Rice Varieties on High Nighttime Temperature (HNT). Treatments at Different Reproductive Stages. In BR Wells Arkansas Rice Research Studies 2019 (34-38). Arkansas Agricultural Experiment Station, Research Series 667. Fayetteville, AR: University of Arkansas System, Division of Agriculture.

Fitzgerald, G. J., Scow, K. M., \& Hill, J. E. (2000). Fallow Season Straw and Water Management Effects on Methane Emissions in California Rice. Global Biogeochemical Cycles, 14, 767-776. https://doi.org/10.1029/2000GB001259

Gorh, D., \& Baruah, K. K. (2019). Estimation of Methane and Nitrous Oxide Emission from Wetland Rice Paddies with Reference to Global Warming Potential. Environmental Science and Pollution Research, 26, 16331-16344.

https://doi.org/10.1007/s11356-019-05026-Z

Groot, T. T., van Bodegom, P. H., Meijer, H. A. J., \& Harren, F. J. M. (2005). Gas Transport through the Root-Shoot Transition Zone of Rice Tillers. Plant and Soil, 277, 107-116.

https://doi.org/10.1007/s11104-005-0435-4

Hidayati, N., Triadiati, \& Anas, I. (2016). Photosynthesis and Transpiration Rates of Rice Cultivated under the system of Rice Intensification and the Effects on Growth and Yield. HA YATI Journal of Biosciences, 23, 67-72.

https://doi.org/10.1016/j.hjb.2016.06.002 
Horie, T. (2019). Global Warming and Rice Production in Asia: Modeling, Impact Prediction and Adaptation. Proceedings of the Japan Academy, Ser. B, Physical and Biological Sciences, 95, 211-245. https://doi.org/10.2183/pjab.95.016

Hou, A. X., Chen, G. X., Wang, Z. P., Van Cleemput, O., \& Patrick Jr., W. H. (2000). Methane and Nitrous Oxide Emissions from a Rice Field in Relation to Soil Redox and Microbiological Processes. Soil Science Society of America Journal, 64, 2180-2186. https://doi.org/10.2136/sssaj2000.6462180x

Huang, Y., Jiao, Y., Zong, L., Zheng, X., Sass, R. L., \& Fisher, F. M. (2002). Quantitative Dependence of Methane Emission on Soil Properties. Nutrient Cycling in Agroecosystems, 64, 157-167. https://doi.org/10.1023/A:1021132330268

Jia, Z., Cai, Z., Xu, H., \& Li, X. (2001). Effect of Rice Plants on $\mathrm{CH}_{4}$ Production, Transport, Oxidation and Emission in Rice Paddy Soil. Plant Soil, 230, 211-221.

https://doi.org/10.1023/A:1010366631538

Jiang, Z., Raghavan, S. V., Hur, J., Sun, Y., Liong, S.-Y., Hguyen, V. Q., \& Dang, T. V. P. (2019). Future Changes in Rice Yields over the Mekong River Delta Due to Climate Change-Alarming or Alerting. Theoretical and Applied Climatology, 137, 545-555. https://doi.org/10.1007/s00704-018-2617-Z

Kimura, M., Murase, J., \& Lu, Y. (2004). Carbon Cycling in Rice Field Ecosystems in the Context of Input, Decomposition and Translocation of Organic Materials and the Fates of Their end Products (CO2 and CH4). Soil Biology and Biochemistry, 36, 1399-1416. https://doi.org/10.1016/j.soilbio.2004.03.006

Kreye, C., Dittert, K., Zheng, X., Zhang, X., Lin, S., Tao, H., \& Sattelmacher, B. (2007). Fluxes of Methane and Nitrous Oxide in Water-Saving Rice Production in North China. $\mathrm{Nu}$ trient Cycling in Agroecosystems, 77, 293-304. https://doi.org/10.1007/s10705-006-9068-0

Krishnan, P., Ramakrishnan, B., Reddy, K. R., \& Reddy, V. R. (2011). High-Temperature Effects on Rice Growth, Yield, and Grain Quality. Advances in Agronomy, 111, 87-206. https://doi.org/10.1016/B978-0-12-387689-8.00004-7

Liu, Q., Ma, H., Sun, Z., Lin, X., \& Zhou, X. (2019). Translocation Efficiencies and Allocation of Nitrogen, Phosphorus and Potassium in Rice as Affected by Silicon Fertilizer under High Daytime Temperature. Journal of Agronomy and Crop Science, 205, 188201. https://doi.org/10.1111/jac.12313

Lu, Y. H., \& Conrad, R. (2005). In Situ Stable Isotope Probing of Methanogenic Archaea in the Rice Rhizosphere. Science, 309, 1088-1090. https://doi.org/10.1126/science.1113435

Lu, Y., Wassmann, R., Neue, H. U., \& Huang, C. (1999). Impact of Phosphorus Supply on Root Exudation, Aerenchyma Formation and Methane Emission of Rice Plants. Biogeochemistry, 47, 203-218. https://doi.org/10.1007/BF00994923

Lu, Y., Wassmann, R., Neue, H. U., Huang, C., \& Bueno, C. S. (2000). Methanogenic Responses to Exogenous Substrates in Anaerobic Rice Soils. Soil Biology and Biochemistry, 32, 1683-1690. https://doi.org/10.1016/S0038-0717(00)00085-7

Lunga, D., Brye, K. R., Slayden, J. M., Lebeau, S. G., Roberts, T. L., \& Norman, R. L. (2019). Water Management Effects on Trace Gas Emissions under Greenhouse Conditions from Direct-Seeded Hybrid Rice in a Silt-Loam Soil. In BR Wells Arkansas Rice Research Studies 2019 (191-194). Arkansas Agricultural Experiment Station, Research Series 667. Fayetteville, AR: University of Arkansas System, Division of Agriculture.

Massey, J. H., Mark, S. C., Epting, J. W., Shane, P. R., Kelly, D. B., Bowling, T. H., Leighton, J. C., \& Pennington, D. A. (2017). Long-Term Measurements of Agronomic Crop Irrigation Made in the Mississippi Delta Portion of the Lower Mississippi River Valley Irri- 
gation. Science, 35, 297-313. https://doi.org/10.1007/s00271-017-0543-y

Massey, J. H., Walker, T. W., Anders, M. M., Smith, M. C., \& Avila, L. A. (2014). Farmer Adaptation of Intermittent Flooding Using Multiple-Inlet Rice Irrigation in Mississippi. Agricultural Water Management, 146, 297-304.

https://doi.org/10.1016/j.agwat.2014.08.023

Moldenhauer, K., Wilson Jr., C. E., Counce, P., \& Hardke, J. (2013). Rice Growth and Development. In J. T. Hadrke (Ed.), Arkansas Rice Production Handbook (pp. 9-20). Little Rock: University of Arkansas Division of Agriculture Cooperative Extension Service MP192.

Nalley, L. L., Linquist, B., Kovacs, K. F., \& Anders, M. M. (2015). The Economic Viability of Alternate Wetting and Drying Irrigation in Arkansas Rice Production. Agronomy Journal, 107, 579-587. https://doi.org/10.2134/agronj14.0468

Ortega, L., Patrick, C., Pereira, A., \& Rojas, C. M. (2019). Investigating Genetic Basis of Resistance to Bacterial Panicle Blight of Rice under Heat Stress Conditions. In BR Wells Arkansas Rice Research Studies 2019 (52-56). Arkansas Agricultural Experiment Station, Research Series 667. Fayetteville, AR: University of Arkansas System, Division of Agriculture.

Reba, M. L., Massey, J. H., Adviento-Borbe, M. A., Leslie, D., Yaeger, M. A., Anders, M., \& Farris, J. (2017). Aquifer Depletion in the Lower Mississippi River Basin: Challengers and Solutions. Journal of Contemporary Water Research \& Education, 162, 128-139. https://doi.org/10.1111/j.1936-704X.2017.03264.x

Rogers, C. W., Brye, K. R., Norman, R. J., Gbur, E. E., Mattice, J. D., Parkin, T. B., \& Roberts, T. L. (2013). Methane Emissions from Drill-Seeded, Delayed-Flood Rice Production on Silt-Loam Soil in Arkansas. Journal of Environmental Quality, 42, 1059-1069. https://doi.org/10.2134/jeq2012.0502

Rogers, C. W., Brye, K. R., Smartt, A. D., Norman, R. J., Gbur, E. E., \& Evans-White, M. A. (2014). Cultivar and Previous Crop Effects on Methane Emissions from Drill-Seeded, Delayed-Flood Rice Production on a Silt-Loam Soil. Soil Science, 179, 28-36. https://doi.org/10.1097/SS.0000000000000039

Sass, R. L., Fisher, F. M., Harcombe, P. A., \& Turner, F. T. (1991a). Mitigation of Methane Emissions from Rice Fields: Possible Adverse Effects of Incorporated Rice Straw. Global Biogeochemical Cycles, 5, 275-287. https://doi.org/10.1029/91GB01304

Sass, R. L., Fisher, F. M., Turner, F., \& Jund, M. F. (1991b). Methane Emissions from Rice Fields as Influenced by Solar Radiation, Temperature, and Straw Incorporation. Global Biogeochemical Cycles, 5, 335-350. https://doi.org/10.1029/91GB02586

Sharifi, H., Hijmans, R. J., Hill, J. E., \& Linquist, B. A. (2018). Water and Air Temperature Impacts on Rice (Oryza sativa) Phenology. Paddy and Water Environment, 16, 467-476. https://doi.org/10.1007/s10333-018-0640-4

Sharma, S. K., Singh, Y. V., Tyagi, S., \& Bhatia, A. (2016). Influence of Rice Varieties, Nitrogen Management and Planting Methods on Methane Emission and Water Productivity. Paddy and Water Environment, 14, 325-333.

https://doi.org/10.1007/s10333-015-0502-2

Simmonds, M. B., Anders, M., Adviento-Borbe, M. A., van Kessel, C., McClung, A., \& Linquist, B. A. (2015). Seasonal Methane and Nitrous Oxide Emissions of Several Rice Cultivars in Direct-Seeded Systems. Journal of Environmental Quality, 44, 103-114. https://doi.org/10.2134/jeq2014.07.0286

Smartt, A. D., Brye, K. R., \& Norman, R. J. (2016). Methane Emissions from Rice Production in the United States: A Review of Controlling Factors and Summary of Research. In Greenhouse Gases (pp. 179-207). London: InTech. https://doi.org/10.5772/62025 
Suduan, G., Tanji, K. K., \& Scardaci, S. C. (2004). Impact of Rice Straw Incorporation on Soil Redox Status and Sulfide Toxicity. Agronomy Journal, 96, 70-76. https://doi.org/10.2134/agronj2004.0070

Tan, X., Shao, D., \& Gu, W. (2018). Effects of Temperature and Soil Moisture on Gross Nitrification and Denitrification Rates of a Chinese Lowland Paddy Field Soil. Paddy and Water Environment, 16, 687-698. https://doi.org/10.1007/s10333-018-0660-0

Trisurat, Y., Aekakkararungroj, A., Ma, H., \& Johnson, J. M. (2018). Basin-Wide Impacts of Climate Change on Ecosystem Services in the Lower Mekong Basin. Ecological Research, 33, 73-86. https://doi.org/10.1007/s11284-017-1510-z

United States Environmental Protection Agency (2016). What Climate Change Means for Arkansas. EPA 430-F-16-006.

https://19january2017snapshot.epa.gov/sites/production/files/2016-09/documents/clim ate-change-ar.pdf

Vepraskas, M. J., \& Faulkner, S. P. (2001). Redox Chemistry of Hydric Soils. In J. L. Richardson, \& M. J. Vepraskas (Eds.), Wetland Soils: Genesis, Hydrology, Landscapes, and Classification (pp. 85-105). Boca Raton: CRC Press, Taylor \& Francis Group. https://doi.org/10.1201/9781420026238.ch4

Wang, J., Hasegawa, T., Li, L., Lam, S. K., Zhang, X., Liu, X., \& Pan, G. (2018). Changes in Grain Protein and Amino Acids Composition of Wheat and Rice under Short-Term Increased $\left[\mathrm{CO}_{2}\right]$ and Temperature of Canopy Air in a Paddy from East China. New Phytologist, 222, 1-22. https://doi.org/10.1111/nph.15661

Wang, Y., Huang, J., Wang, J., \& Fundlay, C. (2017). Mitigating Rice Production Risks from Draught through Improving Irrigation Infrastructure and Management in China. Australian Journal of Agricultural and Resource Economics, 62, 161-176. https://doi.org/10.1111/1467-8489.12241

Watanabe, A., Machida, N., Takahashi, K., Kitamura, S., \& Kimura, M. (2004). Flow of Photosynthesized Carbon from Rice Plants into Paddy Soil Ecosystem at Different Stages of Rice Growth. Plant Soil, 258, 151-160. https://doi.org/10.1023/B:PLSO.0000016545.36421.bc

Wichelns, D. (2016). Managing Water and Soils to Achieve Adaptation and Reduce Methane Emissions and Arsenic Contamination in Asian Rice Production. Water, 8, 141-170. https://doi.org/10.3390/w8040141

Wu, X. H., Wang, W., Yin, C. M., Hou, H. J., Xie, K. J., \& Xie, X. L. (2017). Water Consumption, Grain Yield, and Water Productivity in Response to Field Water Management in Double Rice Systems in China. PLoS ONE, 12, e0189280.

https://doi.org/10.1371/journal.pone.0189280

Xie, L., Lewis, S. M., Auffhammer, M., \& Berck, P. (2019). Heat in the Heartland: Crop Yield and Coverage Response to Climate Change along the Mississippi River. Environmental Resource Economics, 73, 485-513. https://doi.org/10.1007/s10640-018-0271-7

Yang, S., Liu, X., Liu, X., \& Xu, J. (2017). Effect of Water Management on Soil Respiration and NEE of Paddy Fields in Southeast China. Paddy and Water Environment, 15, $787-$ 796. https://doi.org/10.1007/s10333-017-0591-1

Ye, T., Zong, S., Kleidon, A., Yuan, W., Wang, Y., \& Shi, P. (2019). Impacts of Climate Warming, Cultivar Shifts, and Phenological Dates on Rice Growth Period Length in China after Correction for Seasonal Shift Effects. Climate Change, 155, 127-143. https://doi.org/10.1007/s10584-019-02450-5

Yuan, J., Yi, X., \& Cao, L. (2019). Three-Source Partitioning of Methane Emissions from 
Paddy Soils: Linkage to Methanogenic Community Structure. International Journal of Molecular Sciences, 20, 1586-1914. https://doi.org/10.3390/ijms20071586

Zheng, H., Fu, Z., Zhong, J., \& Long, W. (2018). Low Methane Emission in Rice Cultivars with High Radial Oxygen Loss. Plant and Soil, 431, 119-128. https://doi.org/10.1007/s11104-018-3747-x

Zhou, G. P., Cao, W. D., Bai, J. S., Xu, C. X., Zeng, N. H., Gao, S. J., Rees, R. M., \& Dou, F. G. (2020). $\mathrm{CO}_{2}$ Incorporation of Rice Straw and Leguminous Green Manure Can Increase Soil Available Nitrogen (N) and Reduce Carbon and N Losses: An Incubation Study. Pedosphere, 30, 661-670. https://doi.org/10.1016/S1002-0160(19)60845-3 